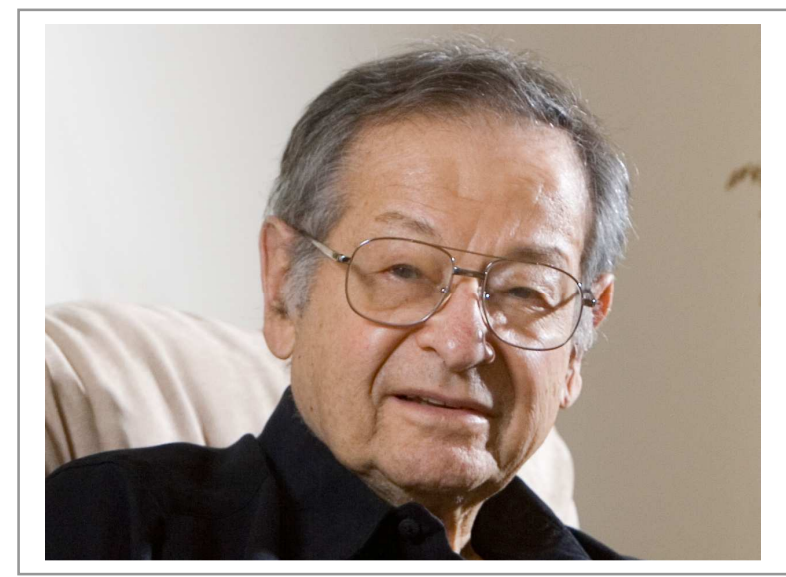

Bernard M. Bass, unul dintre cei mai de seamă autori din sfera psihologiei industrialorganizaționale, a decedat pe 11 Octombrie 2007, în vârstă de 82 de ani.

Bernard Bass a fost distinguished professor emeritus la Şcoala de Management a Universității Binghamton, parte din universitatea de stat din New York. A fost membru al Academy of Senior Professionals, din cadrul Colegiului Eckerd din Florida, precum şi director fondator al Centrului pentru studii de leadership din cadrul Universității Bighamton şi editor fondator al revistei ştiințifice The Leadership Quarterly.

Bernard Bass a primit titlul de doctor în psihologie industrială în 1949 la Ohio State University. Ulterior a predat în cadrul mai multor universități din Louisiana, California (Berkley), Pittsburgh, Rochester şi Binghamton.

În lunga sa carieră, a publicat peste 400 de articole ştiințifice, capitole în cărți, rapoarte tehnice, a fost autorul a 21 de cărți şi a editat alte 10. A fost consultant pentru multe din cele mai prestigioase companii americane. $A$ fost cunoscut şi pentru munca sa pro bono, depusă pentru multe organizații nonprofit, sub formă de workshopuri şi cursuri.

Opera lui este extrem de citată. A fost tradus într-un mare număr de limbi, printre care franceză, germană, spaniolă, portugheză, italiană, japoneză şi, mai nou, română. Atunci când a primit din partea SIOP (Society for Industrial and Organizational Psychology) premiul pentru contribuții deosebite (Distinguished Scientific Contributions Award), cuvântul de decernare a menționat peste 0 duzină de contribuții majore în psihologia industrial-organizațională, printre care munca lui în domeniul discuției de grup fără lider, a feedbackului ulterior evaluării, a întăririi contingente, a educației manageriale participative etc.

Cele mai marcante contribuții ale sale sunt însă în domeniul leadershipului, de care

\section{BERNARD M. BASS}

\author{
$(1925-2007)$
}

numele său este legat indisolubil. În acest domeniu a dezvoltat noi modele teoretice, cel mai celebru dintre toate fiind cel al leadershipului transformațional.

Numeroşi autori consideră, în mod eronat, că întoarcerea la liderul carismatic, la calitățile sale, este inițiată de lucrarea politologului J. Burns, „Leadership” (New York, Harper and Row, 1978). În 1976, la unul din primele simpozioane contemporane de leadership, ținut la Carbondale, Southern Illinois University, ale cărui lucrări au fost publicate în 1977 (J.G.Hunt, L.L.Larson "Leadership. The cutting edge”, Southern Illinois University Press) R. J. House se referă la „A 1976 Theory of Charismatic Leadership” (p.189-207) şi propune operaționalizarea conceptului.

Însă operaționalizarea conceptului de lider carismatic era în gestație, unul din cei care pregăteau noul tip de abordare în conducere fiind Bernard Bass. Încă din 1960, în „Leadership, psychology and organizational behavior”, fără a folosi explicit termenul, Bass se referă la liderul cu capacități deosebite, capabil să-şi motiveze extraordinar adepții, să-i mobilizeze în direcția unor scopuri majore, realizabile pe termen lung.

Interesant este faptul că Bass citează un autor român, G. Popa, care în 1935 publică un studiu de circa 100 de pagini intitulat „Inteligența socială şi psihologia conducătorului” (Cluj, Ed. Revistei „Satul şi şcoala").

În mod special afirmația lui Popa, conform căreia „adevăratul conducător, a cărui înrâurire se resimte în mod efectiv, trebuie să fie bine ancorat în realitățile sociale, să se adapteze în chip desăvârşit şi să proiecteze, peste capul societății, aspirațiile si idealurile de mai bine" (p. 55), a fost reținută de Bernard Bass, iar peste ani, Avolio şi Bass vor dezvolta scalele "Comportamente idealizate" şi „Motivație inspirațională” în chestionarul MLQ. 
Într-una din lucrările sale ("Transformational leadership", 1977) Bass se referă la impactul teoriei respective în mediile industrial, militar şi educațional, având marele merit de a "coborî" liderul transformațional de la nivelul macro la cel micro al organizării sociale. Aşa cum se arăta într-un studiu recent (H. Pitariu, F. Sîntion, "Psihologia luptătorului", 2003): "asistăm la schimbarea paradigmei în psihologia conducerii, inclusiv cea militară. Liderul transformativ, carismatic, strategic renunță la aura sa mistică, ezoterică şi pătrunde în organizații, fiind caracterizat de acțiuni şi comportamente uşor definibile" ( $p$. 14)

$$
\text { Încercările de uniformizare/ }
$$

universalizare a unui tip anume de conducător făcând abstracție de nivelul de conducere şi de caracteristicile organizaționale au avut în timp consecințe uneori dramatice. Astfel, specialiştii militari consideră că teoriile contingente mai mult au amăgit decât au folosit în această instituție. Pentru o organizație care operează cu valori netranzacționabile - patriotismul, spiritul altruist, datoria - sunt necesare alte raporturi lider-subaltern, o altă viziune asupra conducerii. Or, tocmai această alternativă o oferă Bass. În timp ce liderii tranzacționali induc conformism în schimbul unor stimulente concrete, liderii transformativi inspiră adepții să treacă peste interesele personale în interesul unei cauze comune, prin abilitățile lor de a induce mândrie şi tenacitate, stimulare intelectuală, consideratie individualizată.

Munca lui Bernard Bass a fost recunoscută de comunitatea ştiințifică printr-un mare număr de premii, decernate de mai multe organizații profesionale. Cele mai importante dintre acestea sunt Premiul pentru Contribuții Ştiințifice (Distinguished Scientific Contributions Award), primit din partea SIOP în 1994 şi premiul pentru activitatea sa în domeniul leadershipului (Eminent Leadership Scholar Award), primit în 2006 din partea Leadership Network of the Academy of Management.

Putem aprecia că Bass, alături de precursorii citați, este autor de paradigmă în leadershipul contemporan şi viitor. Moartea sa este o pierdere şi un moment trist pentru domeniul psihologiei industrial-organizaționale.

Conf. dr. Dragoş lliescu

\section{D\&D Consultants, Bucureşti www.ddconsultants.ro}

Instrumente psihometrice publicate de D\&D Consultants/TestCentral CPITM (California Psychological Inventory (462, 434, 260)) NPQ ${ }^{\mathrm{TM}}$ (Nonverbal Personality Questionnaire) FFNPQTM (Five-Factor Nonverbal Personality Questionnaire) SWS ${ }^{\mathrm{TM}}$ (Survey of Work Styles) STAXI-2 ${ }^{\mathrm{TM}}$ (State-Trait Anger Expression Inventory) FPITM (Freiburg Personlichkeitsinventar (Formele G şi R)) LSI $^{\mathrm{TM}}$ (Learning Styles Inventory)

MLQTM (Multifactor Leadership Questionnaire (Forma 5X))

STAITM (State-Trait Anxiety Inventory)

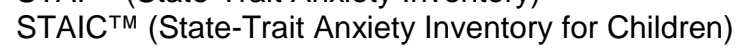

JVIS ${ }^{\text {TM }}$ (Jackson Vocational Interest Survey)

AMI ${ }^{\mathrm{TM}}$ (Achievement Motivation Inventory)

FJAS $^{\text {TM }}$ (Fleishman Job Analysis Survey)

Instrumente psihometrice în curs de apariție: ASSETTM (A Shortened Stress Evaluation Tool) EPQ ${ }^{\mathrm{TM}}-\mathrm{R}$ (Eysenck Personality Questionnaire, Revised) IVETM (Eysenck's Impulsiveness Questionnaire) BFQ ${ }^{\mathrm{TM}}$-2 (Big Five Questionnaire)

BFA $^{T M}$ (Big Five Adjectives)

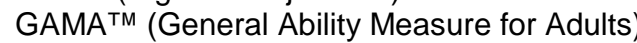

MAB ${ }^{T M}$-II (Multidimensional Aptitude Battery)

NEO-PI-R ${ }^{\mathrm{TM}}$ (Revised NEO Personality Inventory)

BASC-2 ${ }^{\text {TM }}$ (Behaviour Assessment System for Children, Second Edition)

MSCEITTM (Mayer Salovey Caruso Emotional Intelligence Test)

EO-ITM (Emotional Quotient Inventory)

TEDE6 ${ }^{\mathrm{TM}}$ (Test d'évaluation dynamique de l'éducabilité)

DDDI ${ }^{\mathrm{TM}}$ (Dula Dangerous Driving Index) 